\title{
УДК 551.465.7
}

(C) С. Д. Мартьянов ${ }^{1}$, А. Ю. Дворников ${ }^{1}$, В. А. Горчаков ${ }^{1}$, С. Н. Лоза $a^{1,2}$

${ }^{1}$ Санкт-Петербургский филиал Института океанологии им. П.П. Ширшова РАН, Россия

${ }^{2}$ Институт Альфреда Вегенера, Центр полярных и морских исследований им. Гельмгольца, г. Бремерхафен, Германия

martyanov.sd@gmail.com

\section{МОДЕЛЬНЫЕ ОЦЕНКИ ВКЛАДА ЭКОСИСТЕМЫ В ОБМЕН УГЛЕКИСЛЫМ ГАЗОМ МЕЖДУ ОКЕАНОМ И АТМОСФЕРОЙ В БАРЕНЦЕВОМ МОРЕ}

Статья поступила в редакцию 20.12.2016, после доработки 04.02.2017.

Трехмерная математическая экосистемная модель объединена с циркуляционной и ледовой моделями Баренцева моря. Экосистемная модель описывает взаимодействие фитопланктона, зоопланктона, растворенного неорганического азота, суммарного неорганического углерода, щелочности, органических и неорганических частей детрита. В работе приводятся результаты расчетов концентрации хлорофилла- $a$ в период максимального весеннего цветения фитопланктона в Баренцевом море, а также результаты расчетов потока $\mathrm{CO}_{2}$ между атмосферой и морем при различных условиях. Показано соответствие между зонами интенсивного роста фитопланктона в период цветения и положением Полярного фронта. Выполнена оценка интенсивности обмена $\mathrm{CO}_{2}$ между океаном и атмосферой при наличии и отсутствии биологического стока $\mathrm{CO}_{2}$. Для случая без учета океанического биологического стока углекислого газа получено, что максимальные значения потока $\mathrm{CO}_{2}$ из атмосферы в океан наблюдаются непосредственно в районах кромки льда. Для случая учета влияния морской экосистемы на обмен $\mathrm{CO}_{2}$ между океаном и атмосферой показано соответствие зон максимальных значений потока углекислого газа из атмосферы в океан и зон повышенных значений первичной продукции. Основываясь на полученных результатах, сделан вывод, что пространственная изменчивость потока углекислого газа между океаном и атмосферой обусловлена пространственной изменчивостью первичной продукции гораздо в большей степени, чем изменчивостью поверхностной температуры воды.

Ключевые слова: моделирование морских экосистем, биогеохимические циклы, газообмен $\mathrm{CO}_{2}$, Баренцево море.

S. D. Martyanov ${ }^{1}$, A. Yu. Dvornikov 1 , V. A. Gorchakov ${ }^{1}$, S. N. Losa $^{1,2}$

${ }^{1}$ The Saint-Petersburg Branch of the P.P. Shirshov Institute of Oceanology, Russian Academy of Sciences, Russia

${ }^{2}$ Alfred Wegener Institute, Helmholtz Centre for Polar and Marine Research, Bremerhaven, Germany

\section{MODEL ESTIMATES OF THE ECOSYSTEM CONTRIBUTION IN THE CARBON DIOXIDE EXCHANGE BETWEEN THE OCEAN AND THE ATMOSPHERE IN THE BARENTS SEA}

Received 20.12.2016, in final form 04.02.2017.

A three-dimensional mathematical ecosystem model has been combined with a circulation and a sea-ice models of the Barents Sea. The ecosystem model describes the interaction of phytoplankton, zooplankton, dissolved inorganic nitrogen, total inorganic carbon, alkalinity, organic and inorganic parts of detritus. The paper presents the results of calculations of the chlorophyll- $a$ concentration in the period of maximum spring phytoplankton bloom in the Barents Sea, as well as the results of calculations of $\mathrm{CO}_{2}$ flux between the atmosphere and the sea under various conditions. The correspondence between the zones of the intensive growth of phytoplankton during the bloom period and the position of the Polar Front has been demonstrated. The estimation of the ocean-atmosphere $\mathrm{CO}_{2}$ exchange intensity in the presence and absence of the biological $\mathrm{CO}_{2}$ pump has been carried out. For the case without taking into account the oceanic biological uptake of atmospheric carbon dioxide it was found that the maximum values of $\mathrm{CO}_{2}$ flux can be observed in the areas of the ice edge. Taking into account the oceanic biological uptake of atmospheric $\mathrm{CO}_{2}$ leads to the spatial correspondence of

Ссылка для цитирования: Martyanov S. D., Dvornikov A. Yu., Gorchakov V. A., Losa S. N. Model estimates of the ecosystem contribution in the carbon dioxide exchange between the ocean and the atmosphere in the Barents Sеа // Фундаментальная и прикладная гидрофизика. 2017. Т. 10, № 1. С. 11-16.

For citation: Martyanov S. D., Dvornikov A. Yu., Gorchakov V. A., Losa S. N. Model estimates of the ecosystem contribution in the carbon dioxide exchange between the ocean and the atmosphere in the Barents Sea. Fundamentalnaya i prikladnaya gidrofizika. 2017, $10,1,11-16$.

DOI: $10.7868 / \mathrm{S} 2073667317010026$. 
the zones of maximal $\mathrm{CO}_{2}$ flux from the atmosphere and the zones of high primary production in the ocean surface layer. The results of the present study show that the spatial variability of the carbon dioxide flux from the atmosphere to the ocean is determined by the spatial variability of the primary production to a much greater extent than by the variations in the sea surface temperature.

Key words: marine ecosystem modeling, biogeochemical cycles, $\mathrm{CO}_{2}$ exchange, the Barents Sea.

Introduction. The Barents Sea is located on the North-European shelf and is a marginal sea of the Arctic Ocean. By virtue of its geographical location it is influenced by both the Atlantic Ocean and the Arctic Basin, which manifests mainly in the presence of the Polar front - a zone of sharp horizontal gradients of water temperature and salinity. In addition, the Barents Sea is characterized by high biological productivity and is of great interest for fishery. In this respect, the study of the functioning of the Barents Sea ecosystem is important not only from a theoretical point of view but also has obvious practical significance. Finally, the present-day problems of global warming and the increasing concentration of carbon dioxide in the atmosphere are reflected in the Barents Sea study, particularly in the problem of the Arctic sea ice area reduction and ocean uptake of atmospheric $\mathrm{CO}_{2}$.

Today the studies of the ocean-atmosphere carbon dioxide exchange are conducted, in general, in the framework of two approaches:

1. Analysis of observational data, which allows, on the basis of the spatial and temporal variability of the measured parameters and features, to make an assumption about the processes that lead to these features.

2. Modeling, when on the basis of the parameterization of known processes a model can be developed that reproduces the distribution and variability of the studied parameters.

An example of a research in the framework of the first approach is the work [1]. The main obstacles to the use of this approach are the problems associated with data timing spread and its non-uniform distribution over the World Ocean. The consequence of this is the use of the interpolated observational data on coarse grids with large time-averaging that does not allow identifying the dependence of the studied characteristics from the processes with smaller spatial and temporal scale.

The second approach was implemented in works [2-4], in which the processes of $\mathrm{CO}_{2}$ transformation, biogeochemical processes, hydrophysical processes and gas exchange were taken into account. However, these models had a rather coarse spatial resolution that cannot allow assessing the local effects such as fronts and ice cover impact.

The aim of this work was to study the functioning of the primary trophic levels of the Barents Sea marine ecosystem on seasonal and interannual time scales with making use of numerical modeling. To achieve this aim several intermediate tasks were set and solved: 1) modernization of the box model of the marine ecosystem for its further coupling with a three-dimensional model of the circulation and sea ice implemented for the Barents Sea; 2) performing numerical experiments on the sensitivity of the ecosystem model and its calibration; 3) calculation of the basic characteristics of the Barents Sea marine ecosystem for the period 1996 - 2007; 4) evaluation of the influence of sea ice upon the growth rate of phytoplankton in the Barents Sea; 5) evaluation of the influence of biological factors upon the carbon dioxide exchange intensity between the ocean and the atmosphere.

Methods. A coupled 3D model based on the circulation Princeton Ocean Model (POM) [5, 6], sea ice model HELMI [7] and marine ecosystem model [3] was used to simulate the ice regime and ecosystem functionality in the Barents Sea. The model domain and bathymetry are shown in fig. 1, $a$ (see an insert). The spatial grid in the horizontal direction is curvilinear orthogonal with $140 \times 160$ computational nodes (fig. $1, b$ ). In the vertical direction the model uses non-uniform 25 sigma levels with the increased discretization in the upper layers. The same modeling complex, but with another biogeochemical model and without the carbon cycle module, was described and used in [8] to evaluate the effect of sea ice on the primary production in the Barents Sea.

The external forcing for the coupled model includes the sea level and current velocity, water temperature and salinity, sea ice thickness and concentration, as well as the concentration of dissolved inorganic nitrogen taken from the results produced by a global coupled model (ocean + sea ice + marine biogeochemistry) MPIOM/ HAMOCC [9], and is set on the open boundaries of the model domain. For the remaining variables of the ecosystem module the radiation condition is set on the open boundaries. In addition, the model takes as input 
the fields of following meteorological parameters: wind speed and direction, cloudiness, atmospheric pressure at the sea level, precipitation rate, air temperature and humidity in the near-surface layer of the atmosphere (NCEP/NCAR reanalysis is used). On the solid lateral boundaries the no-slip condition is set for the current velocity and the zero flux of heat and salt. At the bottom the vertical velocity, heat and salt fluxes are set to zero. The shear stress at the lower boundary near the bottom is calculated as a function of current velocity at this level with a logarithmic velocity profile. At the upper boundary (water surface) the calculation of atmospheric forcing is made according to recommendations [10] with the diurnal variations of short-wave radiation being taken into account. Wind stress is calculated as a quadratic function. The time series of atmospheric $\mathrm{pCO}_{2}$ is set according to the field measurements at the stations Barrow (Alaska, USA) and Summit (Greenland).

The ecosystem model describes the interaction of phytoplankton, zooplankton, organic and inorganic parts of detritus, dissolved inorganic nitrogen, total inorganic carbon, alkalinity. Dissociation of the inorganic detritus is described according to the parameterization proposed in [11]. $\mathrm{CO}_{2}$ flux at the ocean-atmosphere interface is parameterized through the temperature and salinity of the sea surface, wind shear stress in the lower layer of the atmosphere, sea ice concentration, $\mathrm{CO}_{2}$ partial pressure in the atmosphere and dissolved $\mathrm{CO}_{2}$ concentration in the ocean upper layer, $\mathrm{CO}_{2}$ solubility in water. At the solid lateral boundaries, as well as at the upper and lower boundaries, the absence of biogeochemical variables' flux is considered. The full description of the biogeochemical module of the coupled eco-hydrodynamical model is given in $[3,11]$. The phytoplankton growth rate is calculated with taking into account the effect of water temperature [12], the presence of available nutrients and photosynthetically active radiation. Note that the calculation of photosynthetically active radiation is carried out with taking into account the attenuation of light by water and by phytoplankton self-shading, temperature and nutrient factors, a technique now widely used in the parameterization of the process in the global biogeochemical models [13].

Verification of the model with making use of the satellite measurements of sea surface temperature made by imaging moderate-resolution imaging spectroradiometer MODIS Terra [14] and the area of ice cover measured by the passive microwave sensing [15] showed that the model estimates are close to those observed [8]. Comparison of the calculation results of the Barents Sea ecosystem characteristics (phytoplankton, zooplankton, detritus and nitrate concentration) made by two different models (11-component model of the marine ecosystem [8] and the one used in the current study 7-component ecosystem model including the carbon cycle) showed that the both models with a specific set of model parameters give similar results for these characteristics of the ecosystem. In [8] the 11-component ecosystem model verification against observational data was carried out for six different areas of the Barents Sea and showed good quality of simulation of the primary production and surface chlorophyll- $a$ concentration. That results were compared and were found to be close with the results obtained by the currently used 7-component ecosystem model for these two characteristics, the main difference being the sharper peaks corresponding to the period of the spring bloom (7-component model reproduced them better) and a bit higher values of surface chlorophyll- $a$ concentrations. This conclusion justifies the use of the 7-component model, more effective from a computational point of view, as biogeochemical block of the coupled Barents Sea eco-hydrodynamical model aimed to study the functioning of the biogeochemical processes in this region.

Results and Discussion. Preliminary test calculations revealed that the ecosystem model is most sensitive to the following parameters: the slope of the P-I curve (dependence between photosynthesis of phytoplankton and light intensity), the basic maximum phytoplankton growth rate, and zooplankton grazing rate.

Calculations carried out for the period from 1996 to 2007 showed that the model correctly reproduces the spatial distribution of phytoplankton and other ecosystem characteristics. Ecosystem model calibration was performed using the satellite data of chlorophyll- $a$ concentration in the surface water layer [16]. During that calibration the optimal values of the parameters to which the model is most sensitive were determined. Fig. 2 (see an insert) shows a comparison of the fields of the surface chlorophyll- $a$ concentration obtained by the model (fig. 2, a) and by the satellite measurements (fig. 2,b).

As it can be seen from fig. 2, the model is capable to reproduce the main features of the chlorophyll- $a$ spatial distribution in the Barents Sea during the intensive phytoplankton bloom. High values of calculated chlorophyll- $a$ concentration are in the western and central parts of the Barents Sea with the values of $5-10 \mathrm{mg} / \mathrm{m}^{3}$ and in some areas up to $20 \mathrm{mg} / \mathrm{m}^{3}$. The southern coast of the Barents Sea and the White Sea can also be distinguished as regions with high chlorophyll- $a$ concentration $\left(3-7 \mathrm{mg} / \mathrm{m}^{3}\right)$. Results also show 
overestimated concentrations off the northern coast of the Kola peninsula. It should be added that the model correctly reproduces the start of the period of the phytoplankton bloom in the Barents Sea at the end of Aprilbeginning of May, with the bloom peak in 2005 being in the second half of May. Similar conclusions follow from the analysis of satellite measurements [16]. The quantitative relationship between phytoplankton and zooplankton in the investigated region is demonstrated in fig. 3 which shows the time series of their calculated total biomasses expressed in nitrogen units.

Besides the chlorophyll- $a$ spatial distribution, fig. 2, a also shows the calculated sea ice concentration isolines. The connection between these two characteristics is of particular interest in the Barents Sea because the areas of the ice edge, according to the observations, have high biological productivity due to the presence of sufficient amounts of nutrients after winter period, increasing income of photosynthetically active radiation and high vertical density stability due to freshening of the upper layer [17, 18]. The position of the ice edge separates the areas with high concentrations of chlorophyll- $a$ from the areas where the phytoplankton bloom has not yet started or is weakly expressed. An area off the south-east coast of Svalbard is characterized, according to fig. 2, $a$, by the high concentration of chlorophyll- $a$, and at the same time this area corresponds pretty well to the clearly visible ice edge in this region where the ice compactness isolines are very close to each other. It is known that the phytoplankton blooms in the Barents Sea in spring may occur among and under the sea ice, before its melting or withdrawal. According to the estimates given in [19] the amount of such primary production in the northern part of the Barents Sea can reach 16 to $22 \%$.

The current work is aimed to the study of the carbon dioxide exchange between the atmosphere and the ocean and the role of biological factors in this process. Fig. 4 (see an insert) shows the modeled magnitude of the $\mathrm{CO}_{2}$ flux between the ocean and the atmosphere in the case of the absence of any biological factors' influence, as well as the contours of ice concentration and sea surface temperature distribution on May 20, 2007.

Fig. 4, $a$ shows that the maximum $\mathrm{CO}_{2}$ flux (positive from the atmosphere into the ocean) is in the areas of the ice edge. This is due to the relatively low water temperature in these areas (fig. $4, b$ ) and reduced sea surface salinity due to the fresh water produced during the ice melting. It enhances the solubility of the carbon dioxide in the water. In addition, the overall increase of the free water surface area also contributes to the free gas exchange. All these features are taken into account in the biogeochemical model. The obvious minimum of the $\mathrm{CO}_{2}$ flux is seen in the vast western and south-western areas of the Barents Sea due to the inflow of more warm and salty Atlantic water in which the gas solubility is lower.

The influence of biological factors upon the $\mathrm{CO}_{2}$ exchange manifests in the fact that during its growth the phytoplankton assimilates some part of the dissolved carbon dioxide. During this process the partial pressure of $\mathrm{CO}_{2}$ in the upper ocean layer is reduced, which increases the $\mathrm{CO}_{2}$ flux from the atmosphere into the ocean. Fig. 5, $a$ (see an insert) shows a similar to the previous situation for the same instant (May 20, 2007) but with «switched on» biological sink of $\mathrm{CO}_{2}$ in the ocean in the form of carbon assimilation by phytoplankton, all the other parameters of the model being the same.

It is easy to note the obvious correspondence between the zones with maximal $\mathrm{CO}_{2}$ flux (fig. $5, a$ ) and the zones with high primary production (fig. $5, b$ ). An exception is the White Sea where, despite the increased primary production, the carbon dioxide solubility is lowered due to the relatively high water temperature (fig. $4, b$ ). In addition, it should be emphasized that the employed ecosystem model was not tuned for the White Sea area, thus the calculation results of biogeochemical variables for this sea cannot be considered reliable.

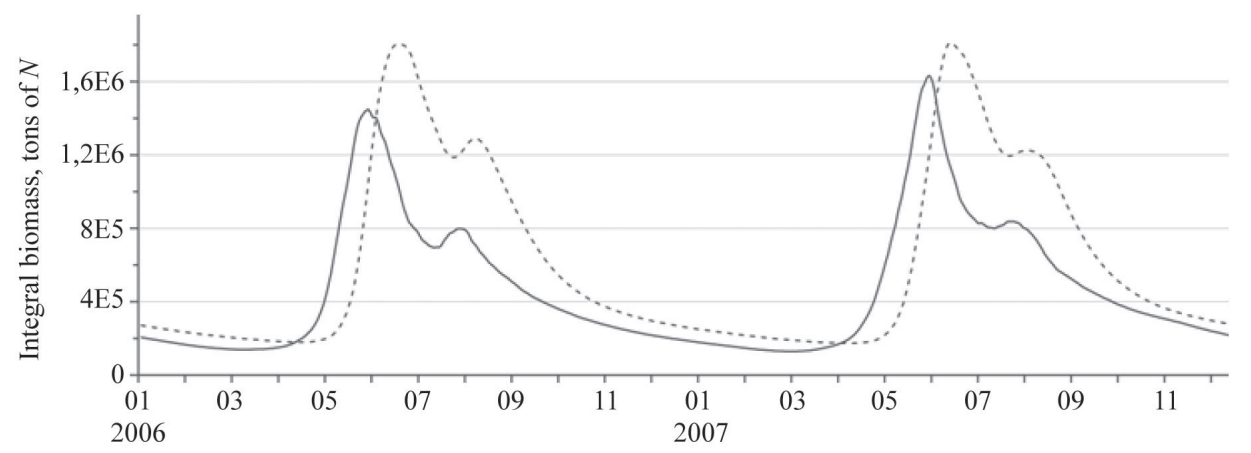

Fig. 3. Total calculated biomass of phytoplankton (solid line) and zooplankton (dotted line) in the model domain in 2006 -2007. 
Of course, all of the above discussion about the influence of the ice edge upon the intensity of gas exchange by means of physical factors only remains valid and the second distinct $\mathrm{CO}_{2}$ flux maximum in the central part of the Barents Sea at the ice edge in fig. 5, $a$ (also seen in fig. 4, a) can be explained by them. At the same time the areas characterized by the intense growth of phytoplankton, which often correspond to the ice marginal zone in the Barents Sea, further enhance the assimilation of atmospheric $\mathrm{CO}_{2}$. Based on these results, it can be concluded that the spatial variability of the carbon dioxide flux between the ocean and the atmosphere is determined by the spatial variability of the primary production to a much greater extent than by the variations in the sea surface temperature.

The role of marine ecosystem in the absorption of atmospheric $\mathrm{CO}_{2}$ can be seen from fig. 6, which shows the time series of the computed $\mathrm{CO}_{2}$ flux from the atmosphere into the ocean in 2006-2007 averaged over the entire area of the model. Taking into account the marine pelagic ecosystem leads to the sharp increase in the absorption of $\mathrm{CO}_{2}$ by the ocean during the phytoplankton growth in May-June ( $2-5$ times more). In addition, taking into account the marine ecosystem also leads to a shift of about one and a half months forward of the start of the period when the ocean begins to release $\mathrm{CO}_{2}$ back to the atmosphere. Note that almost during the entire year (except for one or two months in the second half of the summer) the ocean absorbs $\mathrm{CO}_{2}$ from the atmosphere. This result is consistent with the currently available information on carbon fluxes between the ocean and the atmosphere in this area $[20,21]$.

Conclusions. The results of the present study can be summarized as follows.

1) A 7-component marine pelagic ecosystem model has been coupled with a three-dimensional circulation and sea-ice model of the Barents Sea. 2) A sensitivity study for the ecosystem model has been carried out. 3) Calibration of the ecosystem model was made through the comparison of the computed and measured (satellite data) chlorophyll- $a$ surface concentration. It has been shown that the model correctly simulates the general pattern of the chlorophyll- $a$ spatial distribution in the Barents Sea during the intensive spring bloom. 4) The correspondence between the zones of the intensive growth of phytoplankton during the bloom period and the position of the Polar Front has been demonstrated. 5) The estimation of the ocean-atmosphere $\mathrm{CO}_{2}$ exchange intensity in the presence and absence of the biological $\mathrm{CO}_{2}$ pump has been carried out. 6) For the case without taking into account the oceanic biological uptake of atmospheric carbon dioxide it was found that the maximum values of $\mathrm{CO}_{2}$ flux can be observed in the areas of the ice edge. 7) Taking into account the oceanic biological uptake of atmospheric $\mathrm{CO}_{2}$ leads to the spatial correspondence of the zones of maximal $\mathrm{CO}_{2}$ flux from the atmosphere and the zones of high primary production in the ocean surface layer. 8) The results of the present study show that the spatial variability of the carbon dioxide flux from the atmosphere to the ocean is determined by the spatial variability of the primary production to a much greater extent than by the variations in the sea surface temperature.

Further development of the presented biogeochemical model will be focused on the inclusion of at least another one type of phytoplankton, the addition of silicon and phosphorus as limiting nutrients, and the addition of the benthic layer model. In this case, we can expect to receive the results showing the seasonal dynamics in the change of phytoplankton species, as well as obtaining the correct estimates of the primary production in the shallow White Sea where the benthic layer impact to the total nutrient pool can be significant. More of it,

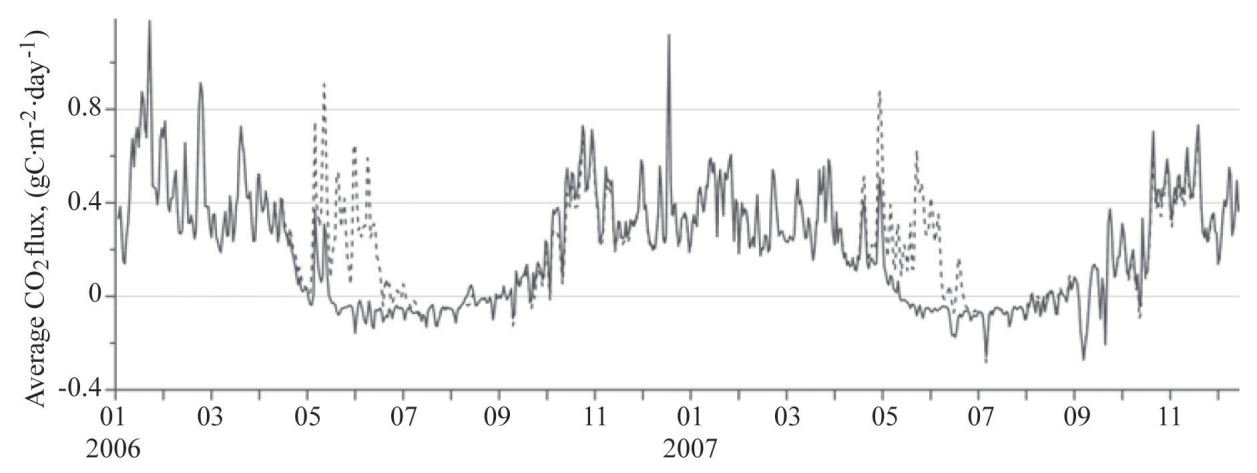

Fig. 6. Modeled $\mathrm{CO}_{2}$ flux from the atmosphere to the ocean in 2006-2007 averaged over the model domain. The model runs were carried out without (solid line) and with (dotted line) taking into account the marine ecosystem impact. 
the currently used POM circulation model will be replaced by a modern MITgcm [17] designed for the parallel calculations that will greatly reduce the total time of the model integration, thus enabling to increase the spatial resolution and to include other areas in the model domain.

This work was supported by the grant № 16-55-76021 of the Russian Foundation for Basic Research. We also would like to thank two anonymous reviewers for their helpful comments and suggestions.

\section{References}

1. Karlin L. N., Malinin V. N., Gordeeva S. M. On the influence of the sea surface temperature on the carbon dioxide exchange with the atmosphere. Oceanology. 2015, 55 (1), 11-19, doi:10.1134/S0001437015010099.

2. Yakushev E. V., Mikhailovsky G. E. Mathematical modelling of the influence of marine biota on the carbon dioxide ocean-atmosphere exchange in high latitudes. Air-Water Gas Transfer, selected papers from the Third International Symposium on Air-Water Gas Transfer, July 24-27, Heidelberg University, edited by B. Jaehne and E. C. Monahan, AEON Verlag \& Studio, Hanau, 1995, P. $37-48$.

3. Popova E. E., Ryabchenko V. A., Fasham M. J. R. Biological pump and vertical mixing in the Southern ocean: Their impact on atmospheric $\mathrm{CO}_{2}$. Global Biogeochemical Cycles. 2000, 14 (1), 477-498.

4. Popova E. E., Yool A., Aksenov Y., Coward A. C., Anderson T. R. Regional variability of acidification in the Arctic: a sea of contrasts. Biogeosciences. 2014, 11, 293-308.

5. Blumberg A. F., Mellor G. L. A description of a three-dimensional coastal ocean circulation model. Three-dimensional Coastal Ocean Models. Ed. N. Heaps. American Geophysical Union, 1987. 208 p.

6. Mellor G. L. Users guide for a three-dimensional, primitive equation numerical ocean model. Program in Atmospheric and Oceanic Sciences. Princeton University, Princeton, NJ, 2004. 56 p.

7. Haapala J., Lonnroth N., Stossel A. A numerical study of open water formation in sea ice. Journal of Geophysical Research. 2005 , 110, C09011, doi:10.1029/2003JC002200.

8. Ryabchenko V. A., Gorchakov V. A., Dvornikov A. Yu., Pugalova S. S. Estimating the effect of ice on the primary production of phytoplankton in the Barents Sea (based on three-dimensional modeling). Fundamentalnaya i prikladnaya gidrofizika. 2016, 9(1), $41-51$ (in Russian).

9. Sein D. V., Mikolajewicz U., Groger M., Fast I., Cabos W., Pinto J. G., Hagemann S., Semmler T., Izquierdo A., Jacob D. Regionally coupled atmosphere-ocean-sea ice-marine biogeochemistry model ROM: 1. Description and validation. J. Adv. Model. Earth Syst. 2015, 7, 268-304.

10. Parkinson C. L., Washington W. M. A large-scale numerical model of sea ice. Journal of Geophysical Research. 1979,84 (C1), $311-337$.

11. Heinze C., Maier-Reimer E., Winn K. Glacial pCO2 reduction by the world ocean: experiments with the Hamburg carbon cycle mode. Paleoceanography. 1991, 6 (4), 395-430.

12. Eppley R. W. Temperature and phytoplankton growth in the sea. Fishery Bulletin. 1972, 70, 4, 1063-1085.

13. Laufkotter C., Vogt M., Gruber N., Aita-Noguchi M., Aumont O., Bopp L., Buitenhuis E., Doney S. C., Dunne J., Hashioka T., Hauck J., Hirata T., John J., Le Quere C., Lima I. D., Nakano H., Seferian R., Totterdell I., Vichi M., Volker C. Drivers and uncertainties of future global marine primary production in marine ecosystem models. Biogeosciences. 2015, 12, 6955—6984, doi:10.5194/bg12-6955-2015.

14. [Web page] Ocean Color Web. URL: http://oceancolor.gsfc.nasa.gov/cgi/13. (Date of access: 02.09.2015).

15. [Web page] NOAA/NSIDC Climate Data Record of Passive Microwave Sea Ice Concentration, Version 2. URL: http://nsidc.org/ data/G02202. (Date of access: 02.09.2015).

16. [Web page] Ocean productivity. URL: http://orca.science.oregonstate.edu/1080.by.2160.8day.hdf.chl.seawifs.php (Date of access: 30.11.2016).

17. Engelsen O., Hegseth E. N., Hop H., Hansen E., Falk-Petersen S. Spatial variability of chlorophyll-a in the Marginal Ice Zone of the Barents Sea, with relation to sea ice and oceanographic conditions. Journal of Marine Systems. 2002, 35, $79 — 97$.

18. Kushnir V., Pavlov V., Morozov A., Pavlova O. «Flashes» of Chlorophyll-a Concentration Derived from in situ and Remote Sensing Data at the Polar Front in the Barents Sea. The Open Oceanography Journal. 2011, 5, 14-21.

19. Qu B., Gabric A. J., Matrai P. A. The satellite-derived distribution of chlorophyll-a and its relation to ice cover, radiation and sea surface temperature in the Barents Sea. Polar Biology. 2006, 29, 196-210.

20. Omar A. M., Johannessen T., Olsen A., Kaltin S., Rey F. Seasonal and interannual variability of the air-sea $\mathrm{CO}_{2}$ flux in the Atlantic sector of the Barents Sea. Marine Chemistry. 2007, 104, 203-213.

21. Lauvset S. K., Chierici M., Counillon F., Omar A., Nondal G., Johannessen T., Olsen A. Annual and seasonal $\mathrm{fCO}_{2}$ and air-sea $\mathrm{CO}_{2}$ fluxes in the Barents Sea. Journal of Marine Systems. 2013, 113 - 114, 62 — 74.

22. [Web page] URL: http://mitgcm.org (Date of access: 05.12.2016). 
К статье Мартьянов С. Д. и др. Модельные оценки...
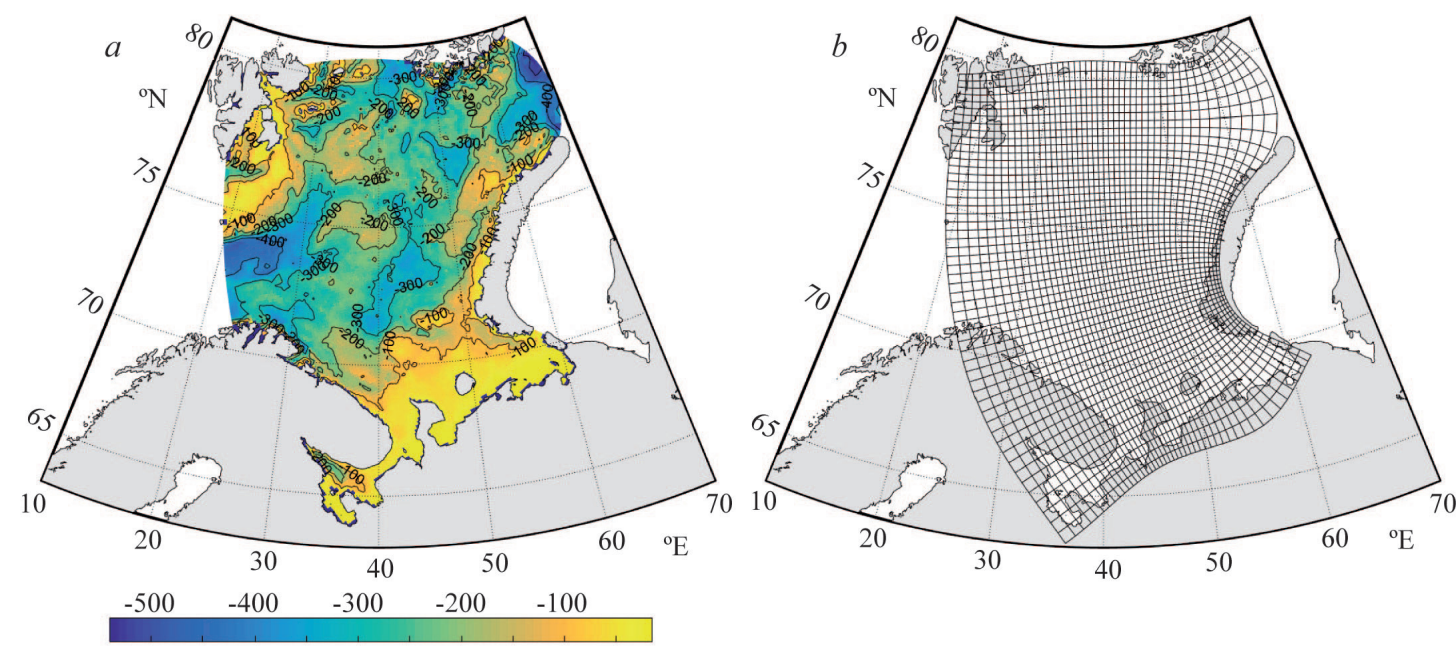

Fig. 1. Model domain. Bathymetry (a) and horizontal computational grid (b).
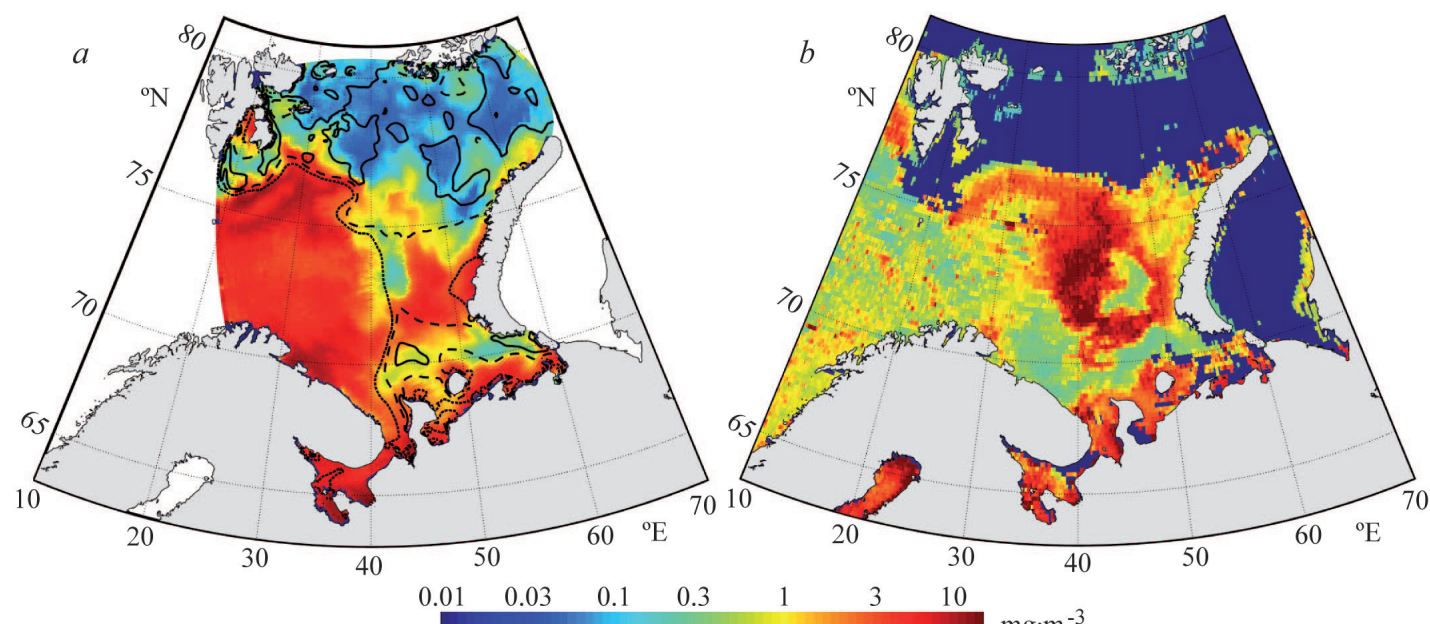

Fig. 2. Surface chlorophyll- $a$ concentration for the 8-day period (25 May - 01 June, 2005). $a$ - Calculated by the model; $b$ - Satellite data (SeaWiFS). Sea ice concentration isolines are also shown (concentration: 0.1 - dotted line, 0.5 - dashed line, 0.8 - solid line). 
К статье Мартьянов С. Д. и др. Модельные оценки...
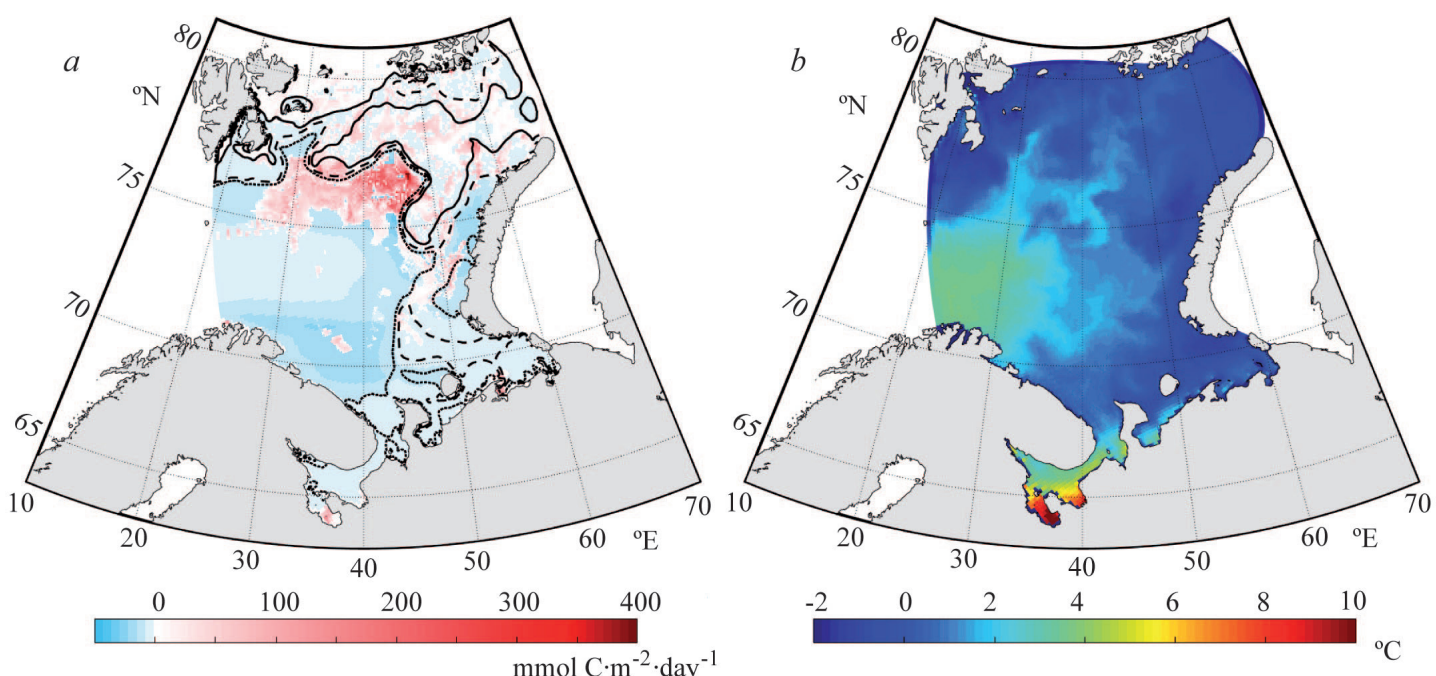

Fig. 4. $\mathrm{CO}_{2}$ flux between the ocean and the atmosphere in the case of the absence of any biological factors' influence; sea ice concentration isolines are shown (concentration: 0.1 - dotted line, 0.5 dashed line, 0.8 — solid line) (a); sea surface temperature. Model results on May 20, 2007 (b).
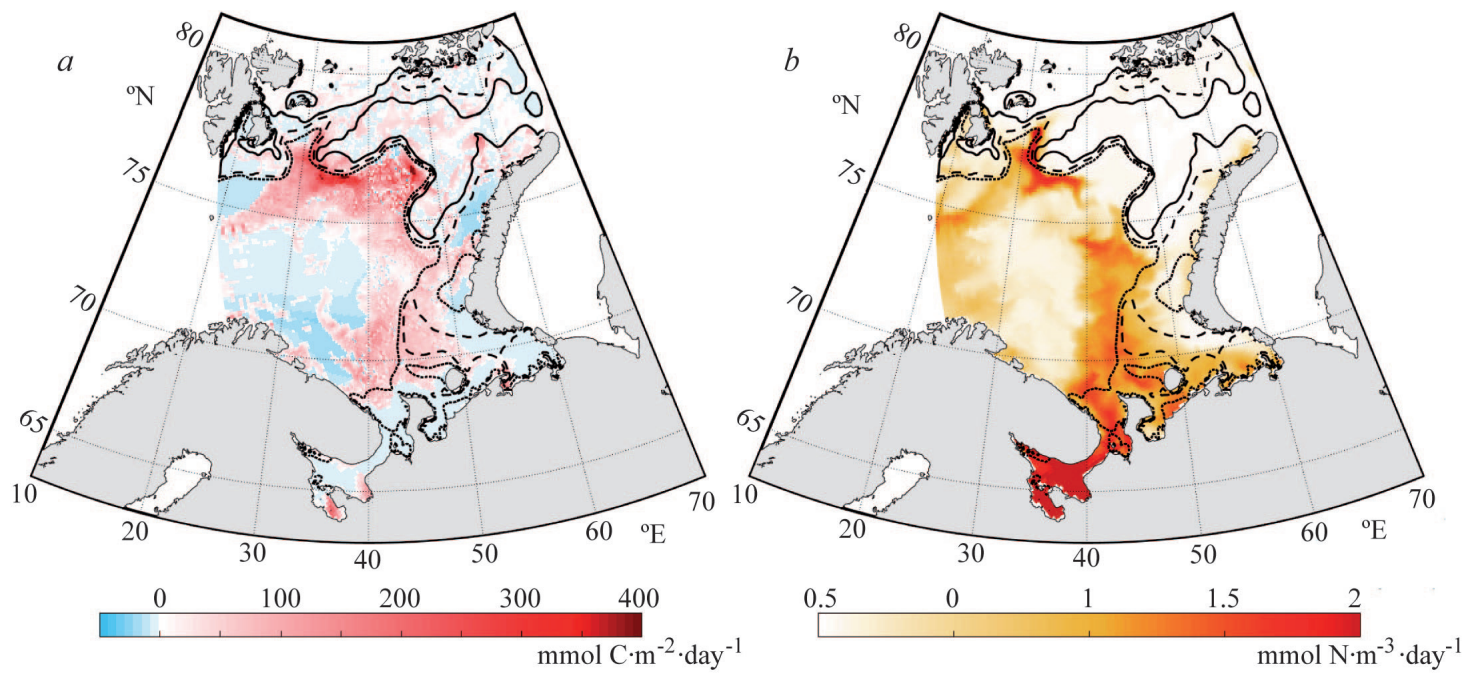

Fig. 5. $\mathrm{CO}_{2}$ flux between the ocean and the atmosphere in the case of taking into account the biological factors' influence; sea ice concentration isolines are shown (concentration: 0.1 - dotted line, 0.5 - dashed line, 0.8 - solid line) (a); Ocean upper layer primary production. Model results on May 20, 2007 (b). 